Citation: Stodolinska, Yu. (2021). American university discourse in the COVID-19 pandemic: Multimodal aspect. Cognitive Studies / Études cognitives, 2021(21), Article 2488. https: //doi.org/10.11649/cs. 2488

\author{
Yuliya Stodolinska 1 \\ Petro Mohyla Black Sea National University, Mykolaiv, Ukraine \\ yuliya.stodolinska@gmail.com
}

\title{
American University Discourse in the COVID-19 Pandemic: Multimodal Aspect
}

\begin{abstract}
This paper examines the transformations that have taken place in the multimodal representation of American university discourse during the COVID-19 pandemic. The first part of the paper investigates how the traditional realization of American university discourse has changed during the coronavirus pandemic. The second part of the paper focuses on the structure, content, role, and characteristic features of the multimodal texts which have been created by American universities as social institutions and have been published on their websites and social media accounts during the pandemic. Overall, it is assumed that during the pandemic the content of the analyzed texts has gradually changed from active propaganda for complete isolation at home to the cautious promotion of reconnecting in a secure surrounding on campus.
\end{abstract}

Keywords: American university discourse; COVID-19; multimodality; multimodal text; nonverbal element; verbal element

\section{Introduction}

Multimodality, as one of the key features of many contemporary discourses, has drawn the attention of scholars from different branches of linguistics for quite a long period of time due to constant technological changes and innovations. Thus, linguists have studied the correlation of linguistic and extralinguistic components in advertising discourse (Kress \& Leeuwen, 2020), the role of several semiotic modes in shaping the literary discourse of fairy-tales (Bekhta, 2014), the creation of multimodal metaphors in the cognitivist framework (Forceville, 2009), and the sociolinguistic aspects of trilingualism in Polish university discourse (Levchuk, 2019). Research has mostly been focused on multimodal aspects of literary, political, advertising, and media discourses (Bargiela-Chiappini \& Planken, 2013; Bieliekhova, 2015; Griebel et al., 2020; Machin \& Leeuwen, 2016; Makaruk, 2014). However, American university discourse has not yet been studied from a multimodal perspective, especially one taking into consideration all the changes which the "new normal" caused by COVID-19 has brought into our lives.

The COVID-19 pandemic has influenced many things. It has altered our communication, travel, meetings and learning habits. The participants of American university discourse have also been greatly impacted by the coronavirus pandemic. University administrators have had to think of alternative forms of education that work in the time of COVID-19 and, at the same time, preserve the rights for equality and inclusion of all the university discourse participants (students, staff, their families, etc.). Administrators have attempted to keep everybody up-to-date with constantly changing information through different channels of communication by creating visual materials, social media posts, etc. Multimodal texts which combine verbal and nonverbal components have 
proved to be one of the most popular and suitable forms of communication for the participants of American university discourse.

The aim of this study is to identify the transformations in the multimodal representation of American university discourse during the COVID-19 pandemic. The first part of the paper investigates how the traditional realization of American university discourse has changed during the pandemic. The second part of the paper focuses on the structure, content, role, and characteristic features of the multimodal texts which have been created by American universities as social institutions and which have been published on their websites and social media accounts during the pandemic.

The methodology of this study is based on the aim and the tasks of the research and requires an integrative multidisciplinary approach. This approach combines the methods and former research findings of such disciplines as discourse studies (the theory of discourse as a cognitive and communicative phenomenon (Bondarenko et al., 2017; Fairclough, 2018; Gee \& Handford, 2012; Karasik et al., 2005; Prikhod'ko, 2013), sociolinguistics (the notion of discourse as a sociocultural phenomenon (Gee \& Handford, 2012), and visual semantics (the relationship between visual images and culturally defined world issues used for creating meaning (Kress \& Leeuwen, 2020). Cognitive and discourse analysis have been used to present information about the main components of American university discourse and to determine the changes that have occurred during the COVID-19 pandemic. Semantic analysis, as well as content analysis, is employed to analyze the multimodal texts created by American universities and to establish their peculiarities. The results of this study are presented in the two subsequent parts, each one focusing on the solution of a set task, followed by general conclusions.

\section{The Changes in Representation of American University Discourse During the COVID-19 Pandemic}

Classification and structural approaches are utilized in this part of the research to define American university discourse and to establish the changes it has experienced during the coronavirus outbreak. The classification approach to discourse analysis is aimed at defining the notion of discourse and researching its typology. Contemporary linguistic explanations of discourse encompass its formal, functional and situational interpretations. Arutiunova (1990) defines discourse as "speech, which is seen as a purposeful social action, as a component involved in the interaction of people and the mechanisms of their consciousness, cognitive processes", as "speech, immersed in life" (pp. 136-137). Shevchenko (2005) emphasizes that discourse is "an integral phenomenon, cognitive and communicative activity, which as a set of process and result, includes both extralinguistic and linguistic aspects; in the latter, in addition to the text, there is a presupposition and context (pragmatic, social, cognitive), which determine the choice of language and speech means" (p. 22). Gee (2014) accentuates the meaning of discourse as not just language-in-use, but a combination of language with other social practices. Thus, according to the situational interpretation, social, psychological and culturally significant conditions and circumstances of communication should be taken into consideration.

Discourses have been classified differently by various scholars. Some linguists differentiate discourses based on their mode (conflict vs. cooperative, democratic vs. totalitarian), sphere (professional, sociocultural, cultural-historic) or style (colloquial, scientific, mass media, official) of communication (Prikhod'ko, 2013, pp. 198-199). Karasik (2007) distinguishes two main types of discourse: personal and institutional. According to this classification, the main feature of institutional discourse is its involvement in social interaction, which takes place mainly within social institutions. Consequently, American university discourse is an institutional discourse. Based on the general definitions and the existing classifications of discourse, in this study American university discourse can be defined as cognitive and communicative activity, restricted by the institutional boundaries of U.S. universities, aimed at the realization of discourse participants' status and role 
capabilities and the achievement of educational, social, business and marketing aims. The structure of this discourse, as well as its main characteristics, distinguish it from other similar types of discourses.

According to the structural approach, the components of discourse context include: ontological context (the configuration of the time and space of communication), communicative context (the communicative competence of the participants, the aim, strategies and tactics, and channel of communication), social context (the biosocial roles of the participants, institutional aspects of communication), psychophysiological context (the psychological and physical state of the participants), cognitive context (the cognitive operations and knowledge of the participants), and psycholinguistic context (the linguistic competence of the discourse participants) (Bezuhla, 2007, pp. 83-85). All these aspects have linguistic or extralinguistic components, the combination of which creates the product of discourse (Karasik, 2007).

In line with the structural approach, the following components of this discourse are defined in order to outline the main features and structure of American university discourse: participants, chronotope, aims, and channels of communication. Detailed analysis of each component and its variations during the COVID-19 pandemic enables the representation of the structure of contemporary American university discourse.

The participants of the analyzed discourse are the representatives of the university (administration, faculty, staff) and existing and potential students. The participants may be classified into internal (those who are already part of the university: administration, faculty, staff, students) and external (potential students and faculty, visitors, press, suppliers, companies, government institutions, etc.). The university is seen as a social institution which plans to achieve certain educational, social, and business aims. The recipients of American university discourse can be classified into two categories: mass recipients and individual recipients. The notion of a mass recipient encompasses people who can be classified according to their department, the degree they are pursuing, their participation in university life, etc. The biosocial roles of participants, their cognitive operations, and knowledge of discourse participants compose the social and cognitive aspects of the analyzed discourse.

The ontological context of the discourse includes the representations of configurations of time and space. Traditionally, the main location of American university discourse consists of university campuses. University websites and social media accounts are supplementary locations. Communication on campuses is regulated by the hours of operation. Time spent on university websites or social media accounts does not have any limits since the participants of the discourse have 24/7 access. Both written and oral communication is common for university campuses, whereas written communication prevails on university websites and social media accounts. During the pandemic, especially throughout its very early stages, most communication was transferred to virtual campuses, available without any time limits on university websites and which provided all necessary information. On-campus communication was limited by certain regulations, rules and additional time frames. There has also been a certain shift to the prevalence of written communication.

The communicative competence of the participants, the aim, strategies and tactics of communication, as well as the communication channels, frame the communicative context of the discourse. The type of discourse determines its main aim. American university discourse strives to achieve educational, social, and business aims: to present information about the university, to offer its educational services, to persuade potential students to study at the university, and to maintain a safe environment for the participants of the educational process. Based on these aims, the main tasks are to inform, educate, persuade, remind, and encourage. The sender of the discourse utilizes the informative and didactical functions of the language to perform the tasks and to achieve the set aims. All of these functions are closely connected and reflect the desire of the sender to inform the recipient about the courses offered and the services provided at the university, their cost, campus news etc. in a way that will allow the sender to influence the recipients and encourage them to enroll as students (business aims). Simultaneously, the sender strives to teach the recipient something new and useful, to promote the need to be a responsible citizen and patriot (educational and 
social aims). In the times of COVID-19, the aim of maintaining a safe environment and informing all the participants of the necessary measures to be taken has become one of the most important ones. Simultaneously, the sender must find a way to achieve the other aims in the new reality.

The website and social media accounts of a university are examples of the main channels of communication for the participants of American university discourse, especially during the COVID-19 pandemic.

The generalized model of American university discourse shown below displays information about the main components of the discourse: discourse participants (sender, recipient), location, time, main aims and channels of communication.

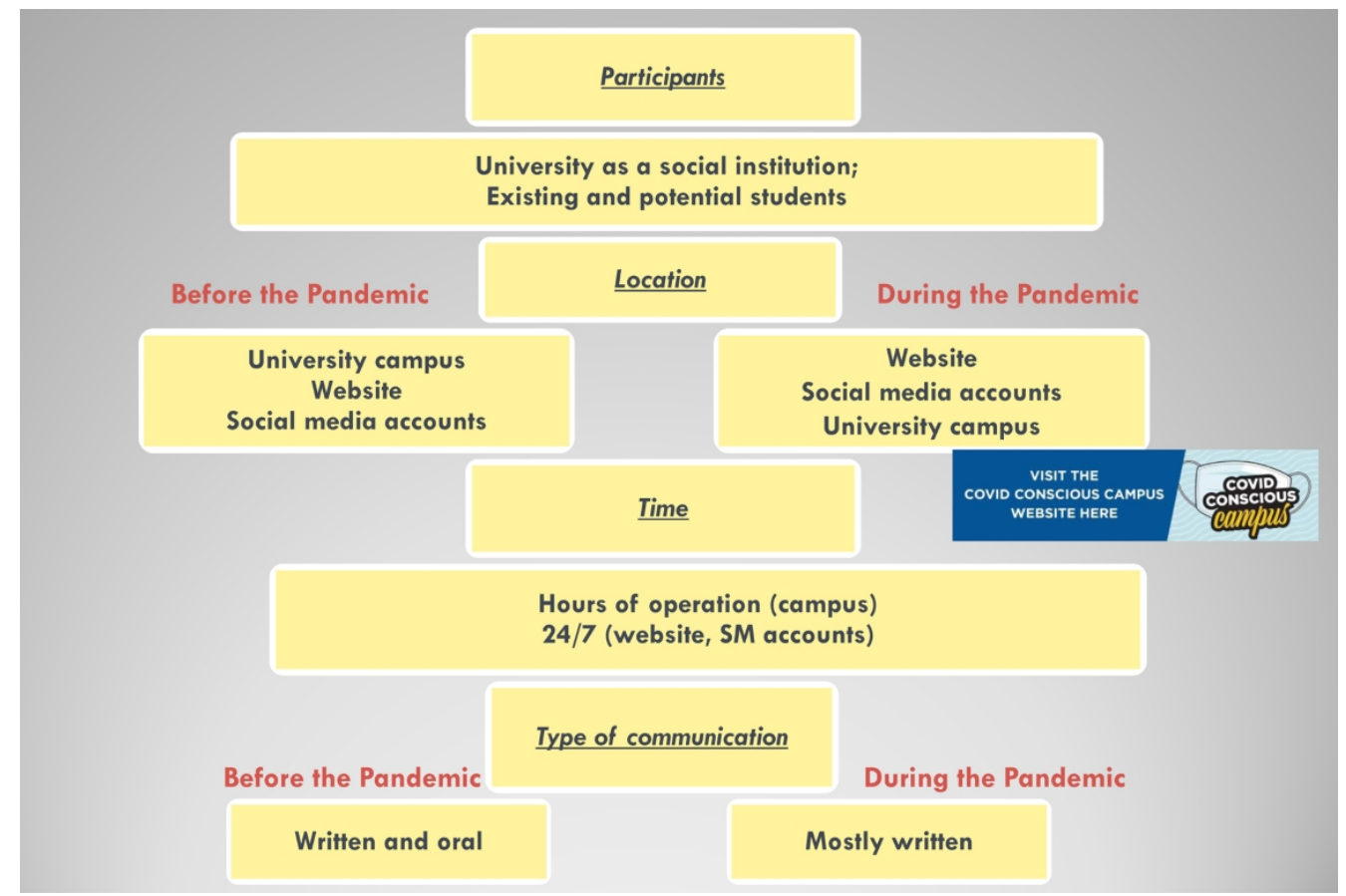

Figure 1. Generalized model of American university discourse.

The cognitive and pragmatic peculiarities of American university discourse define the following characteristics of this discourse:

- multimodality (a combination of verbal and nonverbal components for representing information);

- interaction (ensuring stable communication between all discourse participants, providing information, answers to questions, obtaining feedback from students and their families);

- dynamism (the constant updating of information, instructions and news for all discourse participants);

- consistency (clear and deliberate marketing campaigns for existing and potential students, informational material for staff);

- detail (thorough step-by-step instructions to ensure mutual understanding);

- creativity (utilizing various stylistic devices when creating texts, a successful combination of verbal and nonverbal components);

- didacticism (using multimodal texts for educating an introducing social values). 
On the whole, it can be stated that the model of American university discourse has changed during the COVID-19 pandemic. The communication of the discourse participants has been transferred, at first completely and later partially, to virtual campuses. This has eliminated certain restrictions connected with time and place that existed when most communication occurred on campus and has led to an increase in written communication. The role of websites and social media accounts, which have always been important channels of communication, has increased even more during the pandemic. The characteristic features of American university discourse are interaction, dynamism, consistency, detail, creativity, didacticism and multimodality. This last feature in one of the most important and will be discussed in the next part of the paper.

\section{The Classification of Multimodal Texts Created by American Universities During the COVID-19 Pandemic}

Much of the information on university websites and social media accounts is presented in the form of multimodal texts which contain both verbal and nonverbal elements. During the COVID-19 pandemic these multimodal texts have come to be seen as key elements in the realization of the concept of a safe university environment and vital in communication between sender and recipient. Kress and Leeuwen (2017) in Multimodal Discourse: The Modes and Media of Contemporary Communication define multimodality as the use of several semiotic modes in the design of a semiotic product or event, together with a particular way in which the modes are combined. Ostanina-Olszewska and Majdzińska-Koczorowicz (2019) have researched multimodal texts as multi-level blends that affect our understanding of the world, which is slightly modified every time we "unpack" them. The verbal and non-verbal components create a single visual, structural, semantic, and functional whole that ensures a complex, pragmatic influence on the recipient. Multimodal texts in the analyzed discourse consist of a main and supplementary verbal component, as well as a main and supplementary nonverbal component; together they form a multimodal text which is both informative and attractive for recipients of different backgrounds.

Multimodal texts dedicated to the topic of COVID-19 which appeared on the websites of American universities during the period from February to September 2020 have been selected as material for this research. They can be divided into three groups based on the approximate dates of publication (end of winter - beginning of spring 2020, late spring - middle of summer 2020, end of summer - beginning of fall 2020) and their portrayal of the notion of distance during these time periods.

The First Group, which dates back to the beginning of the pandemic (end of winter - beginning of spring 2020), encompasses multimodal texts which introduce information about COVID-19, its main symptoms, and safety measures to be taken. This group of texts can be characterized by their willingness to inform, protect, and ease the tension caused by fear and uncertainty. One of the main aims of the informational resources was to encourage complete social distancing, as it was seen as the best way to stop the spread of COVID-19.

Among the verbal markers, lexical and syntactic features can be singled out. The lexical peculiarities are the constant usage of the words virus, COVID-19, pandemic. The adjectives novel and new are used to underline the danger of the unknown and the verbs explore, understand prompt the recipient to research information about the new virus and to become aware of the measures that can be taken to prevent it spread. Verbs are used in imperative forms explaining what should be done: stop, stay, wash, wear, practice, etc. The $C D C$ (the Centers for Disease Control and Prevention) are often mentioned in the multimodal texts to add authority to the information. Syntactic features embrace the use of mostly short, emphatic sentences, rarely questions (what is COVID? What are the symptoms? What can you do?), and the use of bullet-point lists. The nonverbal markers are images, graphs and tables which are added to visualize the material presented and to attract the attention of the recipients. The most common are images of the virus, masks, 
soap, and houses. The images of the virus are used mostly in the multimodal texts which contain information about the virus itself. The images of masks, soap, and houses are common in the multimodal texts which promote the safety measures of wearing a mask, washing one's hands and staying at home.

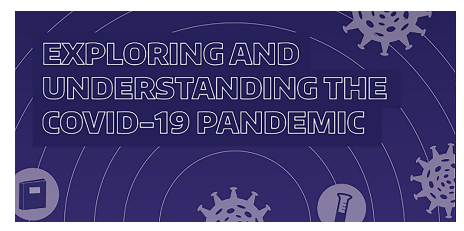

Figure 2. ${ }^{1}$

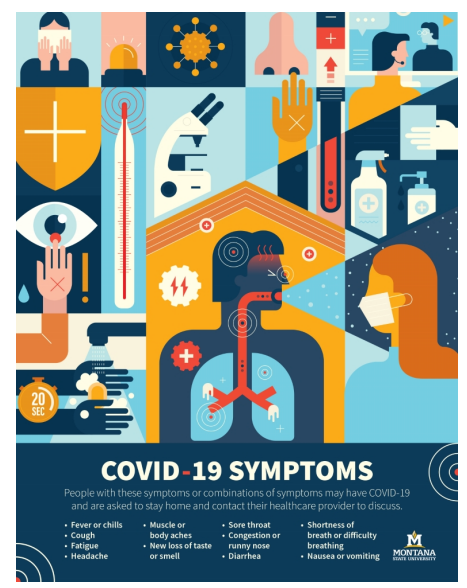

Figure $3 .^{2}$

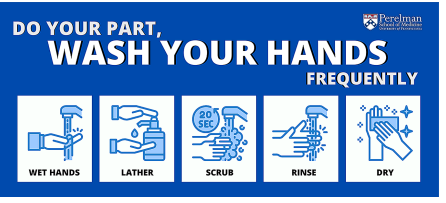

Figure $4 .^{3}$

Social distancing is one of the terms most often used in the multimodal texts and this is the only term which was used to represent distance between people at the beginning of the pandemic.

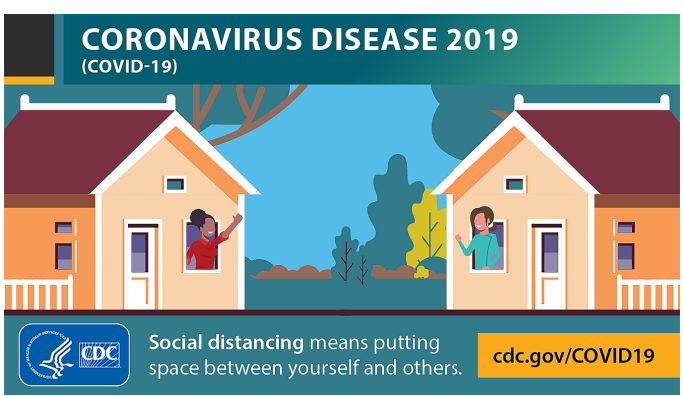

Figure $5 .^{4}$

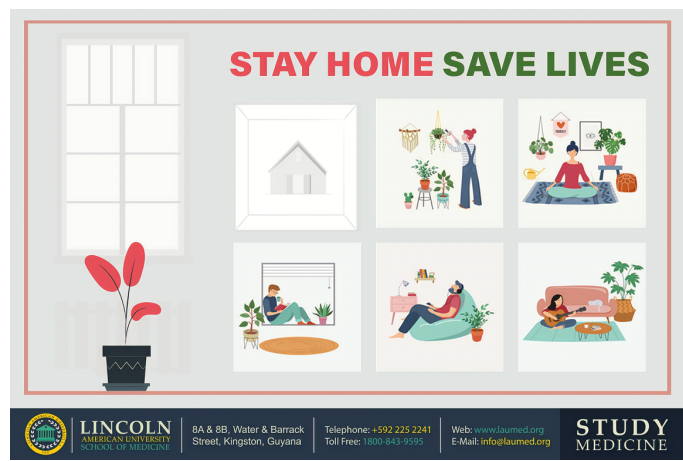

Figure $6 .^{5}$

The combination of verbal and nonverbal elements represents the notion of social distancing as not only keeping $6 \mathrm{ft}$ away from each other, but also staying at home and limiting contact with people as much as possible (Figure 5). Some of the messages urge recipients to practice social distancing by staying at home and engaging in different activities that do not require leaving the house or interacting with other people in person (Figure 6). The multimodal texts can be classified into several categories:

a) informational (providing information on what social distancing is and the 'dos and don'ts' of it)

\footnotetext{
1 https://globalhealth.washington.edu/exploring-and-understanding-covid-19-pandemic

2 https://www.montana.edu/health/coronavirus/covid-download-gallery.html

3 https://www.pcbi.upenn.edu/psom/

${ }^{4}$ https://www.cdc.gov/COVID19

${ }^{5}$ https://m.facebook.com/lincolnamericanuniversity/photos/a.574468126077354/129576376061 4450/? type $=3 \&$ source $=48 \& \_$_tn_-_ $=$EHH-R
} 
b) clarifying (explaining why social distancing is important)

c) providing alternatives (giving suggestions for possible ways to spend time during the pandemic).

An example of an informational multimodal text is this one created by the University of Alabama at Birmingham (Figure 7) to explain what social distancing means and what the 'do's and don'ts' of social distancing are.
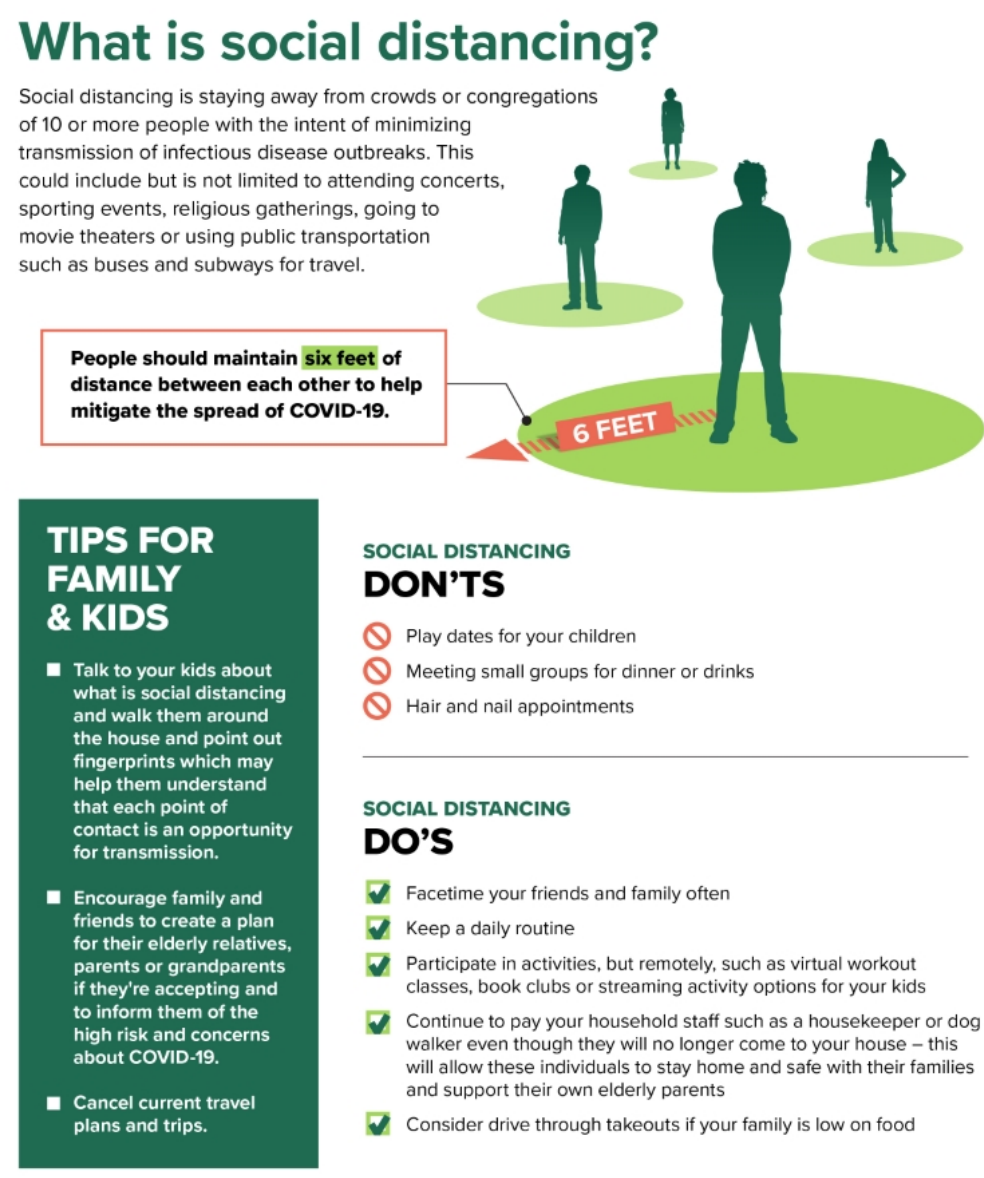

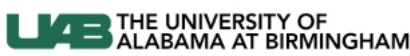

uab.edu/coronavirus

Figure $7 .^{6}$

Among the 'don'ts' are play dates for children and meetings of small groups for dinner or drinks. As an alternative the university suggests using FaceTime frequently with family and friends, as well as participating in classes and clubs remotely.

The clarifying messages promote the necessity to think about your own health, the health of other people around you (especially the elderly and people with unknown underlying health conditions), and the capacity of hospitals. In the multimodal text created by Montana State University (Figure 8), the fact of being able to pass on COVID-19 without showing any symptoms is used as additional motivation to practice social distancing.

${ }^{6}$ https://twitter.com/montanastate/status/1247567190666051585 


\section{Social distancing is not just for your health.}

You can still pass on COVID-19 even if you don't show symptoms. People you meet might

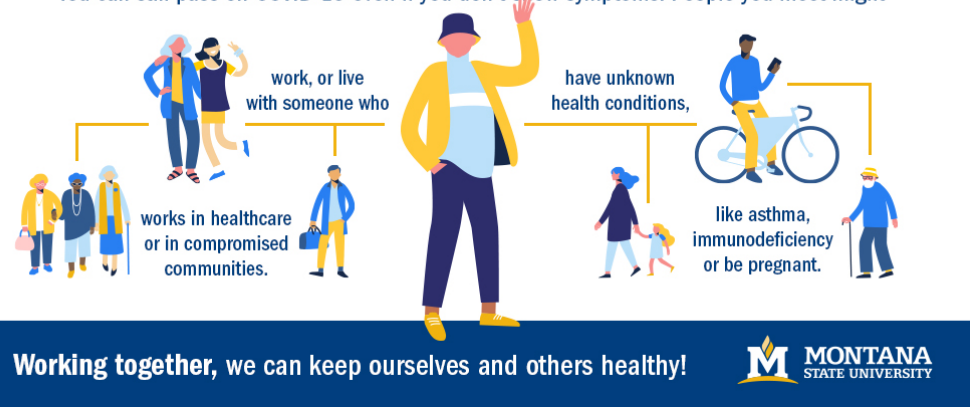

Figure $8 .^{7}$

Messages providing alternatives usually include a list of fun activities which can substitute those no longer possible during the pandemic.

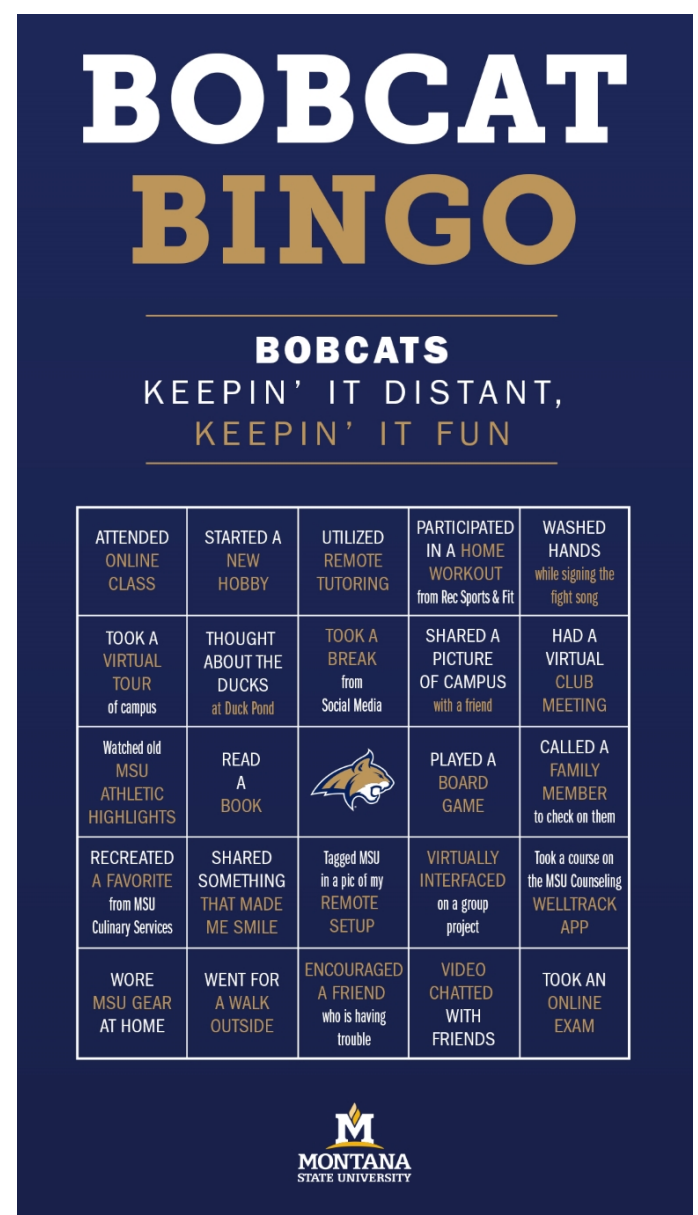

Figure 9. ${ }^{8}$

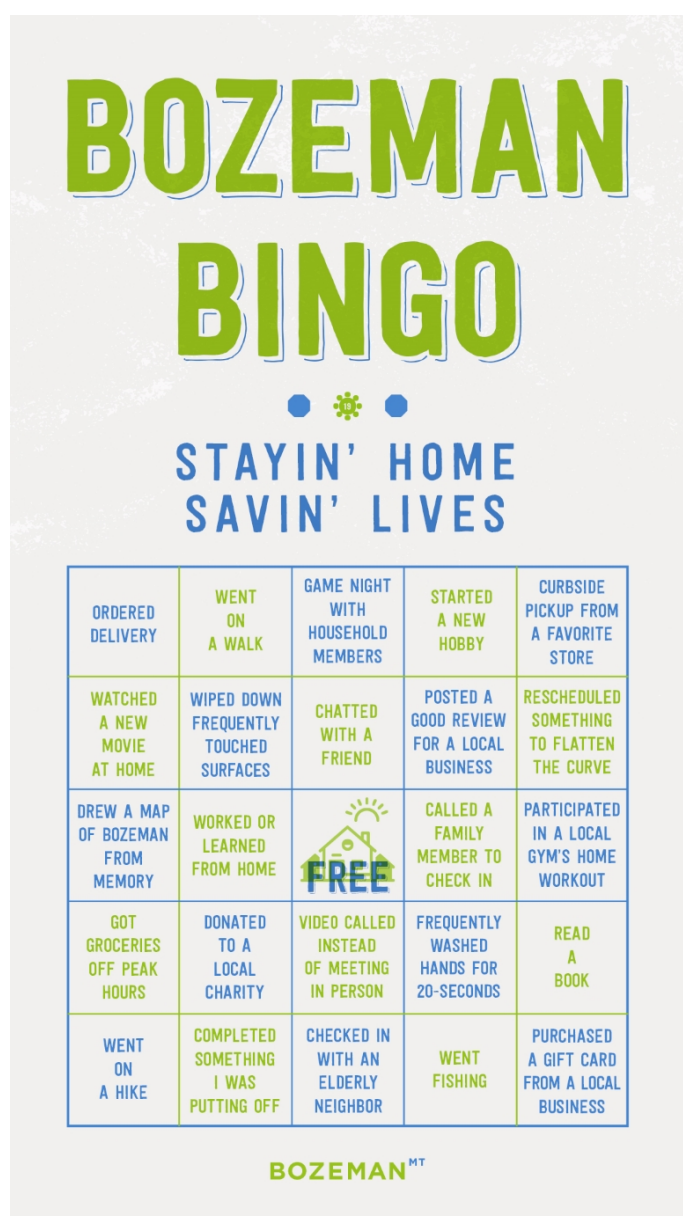

Figure $10 .^{9}$

\footnotetext{
7 https://www .uab.edu/news/youcanuse/item/11186-social-distancing-do-s-and-don-ts

8 https://www.montana.edu/health/coronavirus/images/instagram/BobcatBingo_1080x1920.jpg

9 https://www.montana.edu/health/coronavirus/images/instagram/BozemanBingo_1080x1920.jpg
} 
For example, Montana State University created several versions of Bingo cards with things to do (Figures 9, 10). An emphasis is made on stay-at-home and remote activities, ordering delivery and curb-side pick-up, communicating remotely with family and friends, limiting contacts with unknown people, supporting local businesses. The interplay of the verbal and nonverbal elements adds a humorous and thought-provoking tone to the messages as seen in the examples with fishing (Figure 11) or the cacti (Figure 12).

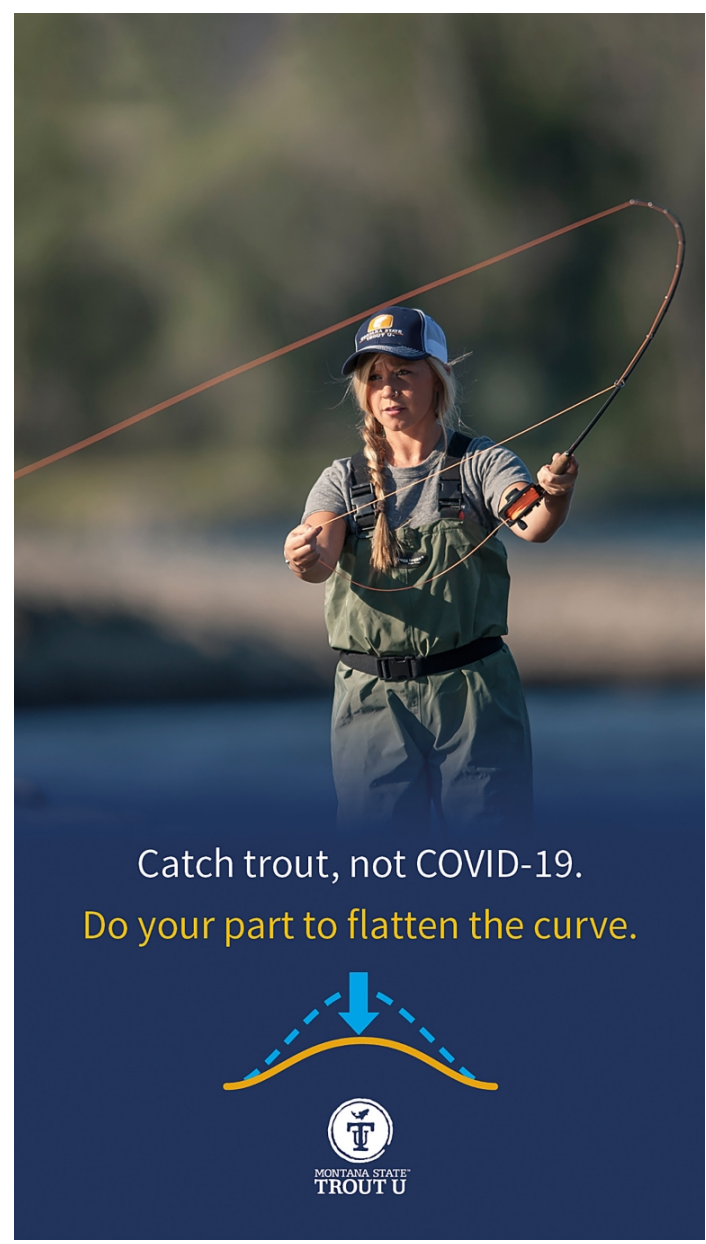

Figure 11. ${ }^{10}$

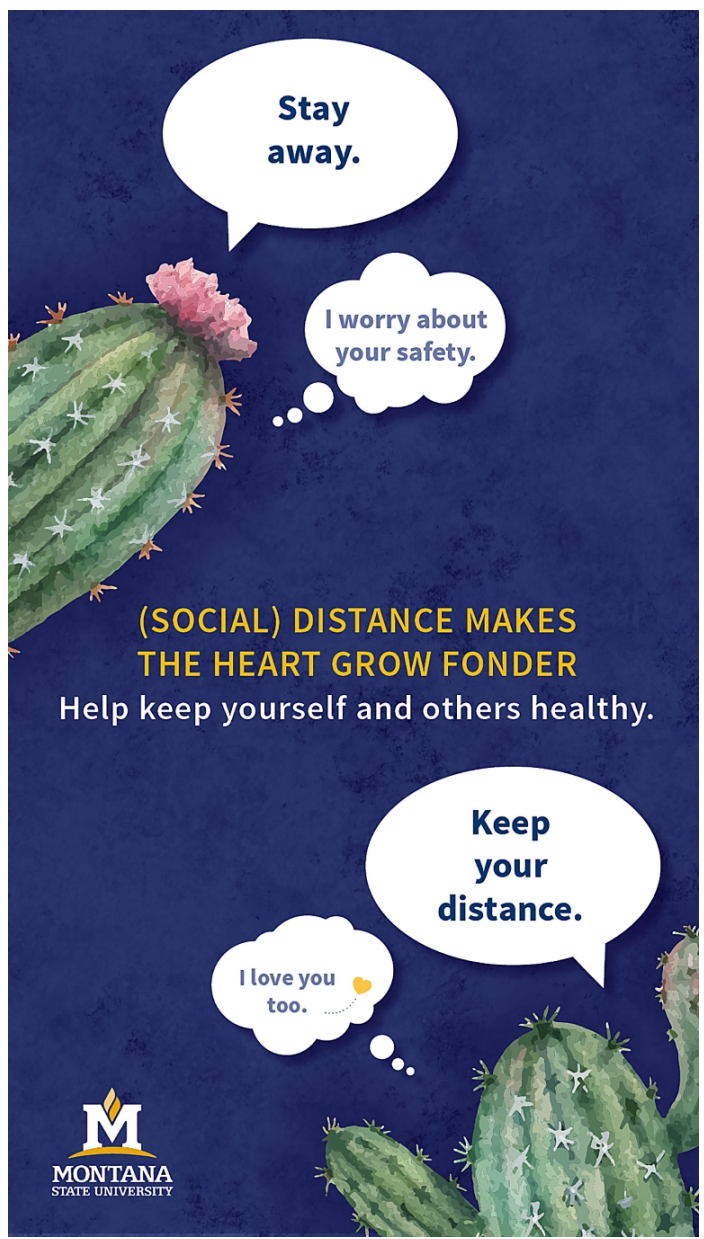

Figure 12. ${ }^{11}$

Nonverbal elements are often used to visualize the alternatives for the activities people are used to and to illustrate what $6 \mathrm{ft}$ looks like and how it can be measured.

\footnotetext{
${ }^{10}$ https://www.montana.edu/health/coronavirus/images/instagram/Fish-1080x1920.jpg

11 https://www . montana.edu/health/coronavirus/images/instagram/Cacti-1080x1920.jpg
} 


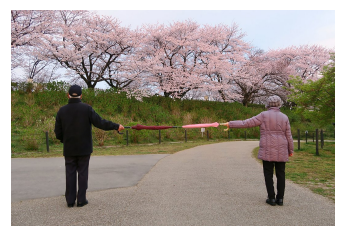

Figure $13 .^{12}$

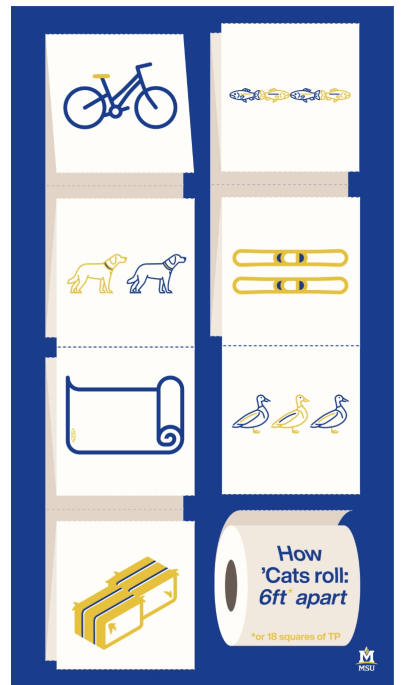

Figure $14 .^{13}$

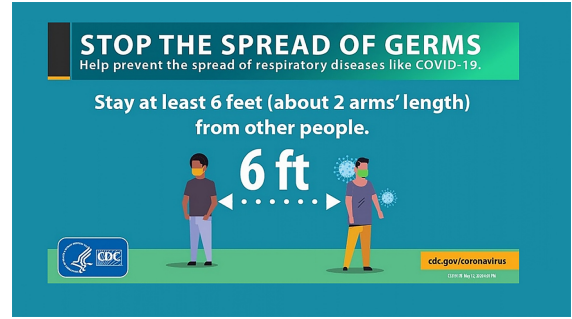

Figure $15 .^{14}$

Some of the examples (Figures 13-15) include measuring $6 \mathrm{ft}$ with umbrellas, dogs, toilet paper or a bike. Many of the images provoke rather humorous associations and are used to attract the attention of as many people from the campus as possible.

Therefore, the first group of multimodal texts which appeared at the end of winter-beginning of spring 2020 is one of the most numerous and is distinguished by its informational character. One of its main functions is to alert recipients to the new virus and the safety measures that should be taken both on and off campus. The combination of verbal and nonverbal elements in the multimodal texts of this group is used to promote complete social distancing and isolation by explaining what it is, why it is needed and what alternatives to normal activities exist.

The Second Group encompasses messages produced in late spring - middle of summer 2020. They are categorized by uncertainty about the future. One of their aims was to give updates on the current situation with COVID-19 and safety measures taken on campus, and to inform recipients about plans for the fall semester, which were changeable and uncertain (Figures 16, 17).

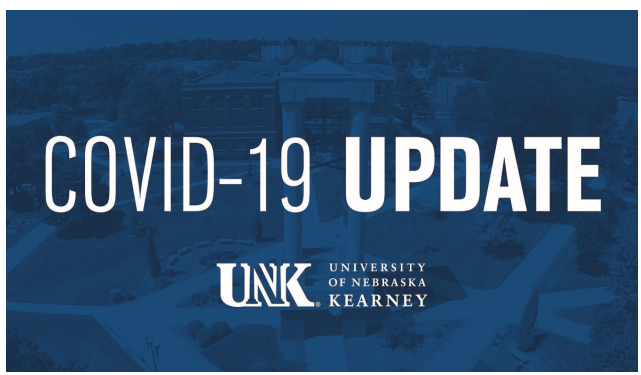

Figure 16. ${ }^{15}$

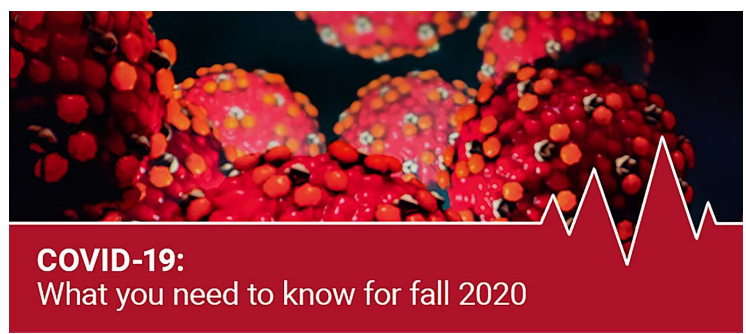

Figure 17. ${ }^{16}$

\footnotetext{
12 https://utswmed.org/medblog/covid-social-distancing/

13 https://www.montana.edu/health/coronavirus/images/instagram/SixFeetTP_1080x1920.jpg

14 https://www.cdc.gov/coronavirus/2019-ncov/communication/stop-the-spread.html\#stop

15 https://www . unk.edu/public-health/index.php

${ }^{16}$ https://www. unmc.edu/gradstudies/current/covid/index.html
} 
The linguistic characteristics of this group include the introduction of the terms the new normal and contact tracing, and frequent usage of the lexemes update, coexist, plans, new rules and guidelines. The nonverbal characteristics of this group are similar to the ones of the first group, with some adjustments. As the lockdown was no longer so strict, the infographics about the coronavirus which were widely used during the first period were complemented with real photos of student and staff wearing masks, and pictures of newsstands (on campus) about the new rules.

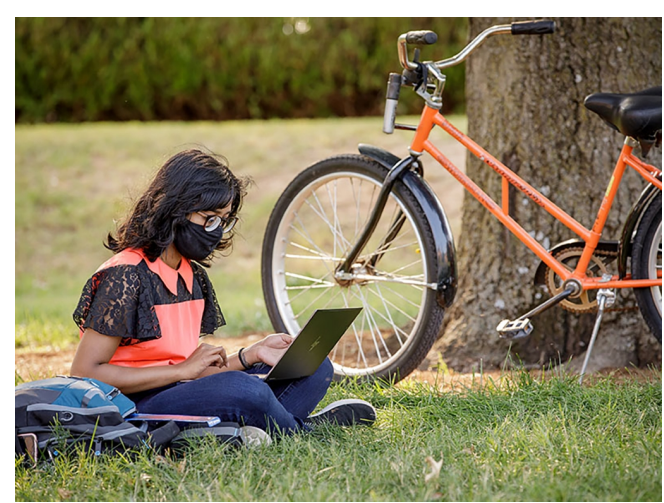

Figure $18 .^{17}$

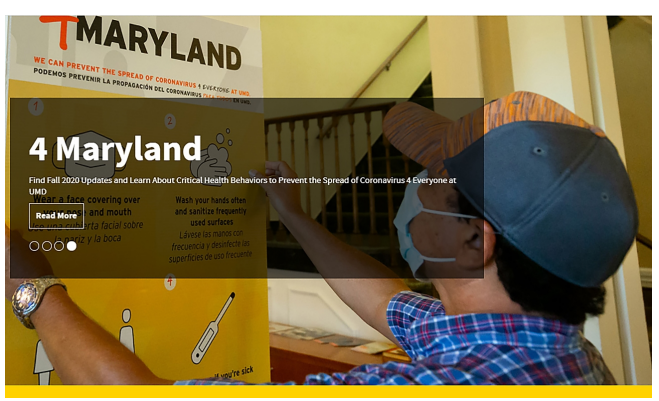

Figure 19. ${ }^{18}$

It should be stated that the photos of people usually show individuals and do not include group photos. In Figure 18, the university shows how a student is studying outside and away from crowds, instead of attending classes in the lecture halls. Figure 19 depicts an example of completing work alone, instead of working together with a partner.

The concept of distance and measures taken to maintain distance between people remained topical at the time this group of messages was produced. However, there was a shift from promoting complete isolation to uncertainty about whether social distancing was the right term or the right solution. Most universities tried to answer the questions How to coexist with COVID-19? How to keep distance and comply with all the rules during the fall semester? Is it possible to conduct classes on campus?

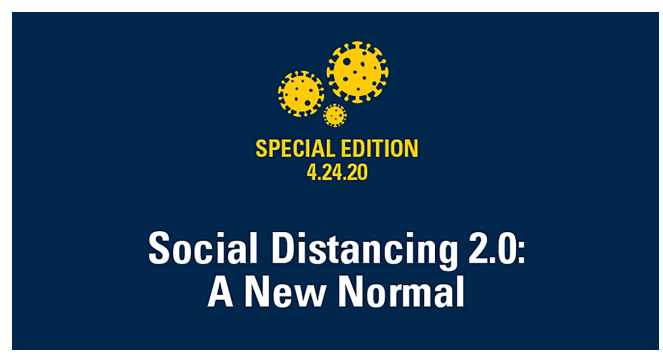

Figure 20. ${ }^{19}$

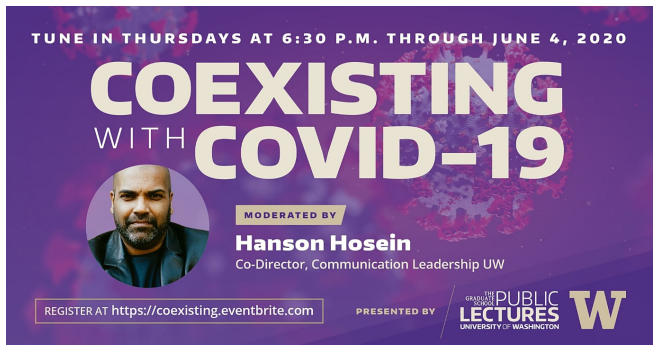

Figure 21. ${ }^{20}$

The multimodal texts in Figures 20 and 21 advertise a podcast launched by the University of Michigan and a lecture series initiated by the University of Washington to explain what changes the pandemic has brought to the lives of university discourse participants, what it means to live in the new normal, and how to coexist with COVID-19.

\footnotetext{
17 https://go.okstate.edu/

18 https://www. umd.edu/

19 https://sph.umich.edu/podcast/coronavirus/social-distancing-a-new-normal.html

20 https://grad.uw.edu/public-lecture-series/coexisting-with-covid-19/
} 
Consequently, the second group of messages which was created in late spring - midsummer 2020 contains a smaller amount of multimodal texts and is characterized by doubt and insecurity. The format of multimodal texts in this group changed from the infographics which were typical of the first group to multimodal texts containing pictures of real people. The concept of complete social distancing (staying at home as much as possible) shifted to the search for alternatives to social distancing and ways of existing in the world under new conditions.

The Third Group of multimodal texts, which were created at the end of summer - beginning of fall 2020, is dedicated to the topic of reopening campuses while keeping everybody safe and healthy. The notion of distance is being rethought and the participants of university discourse are trying to find alternatives to the term social distancing.

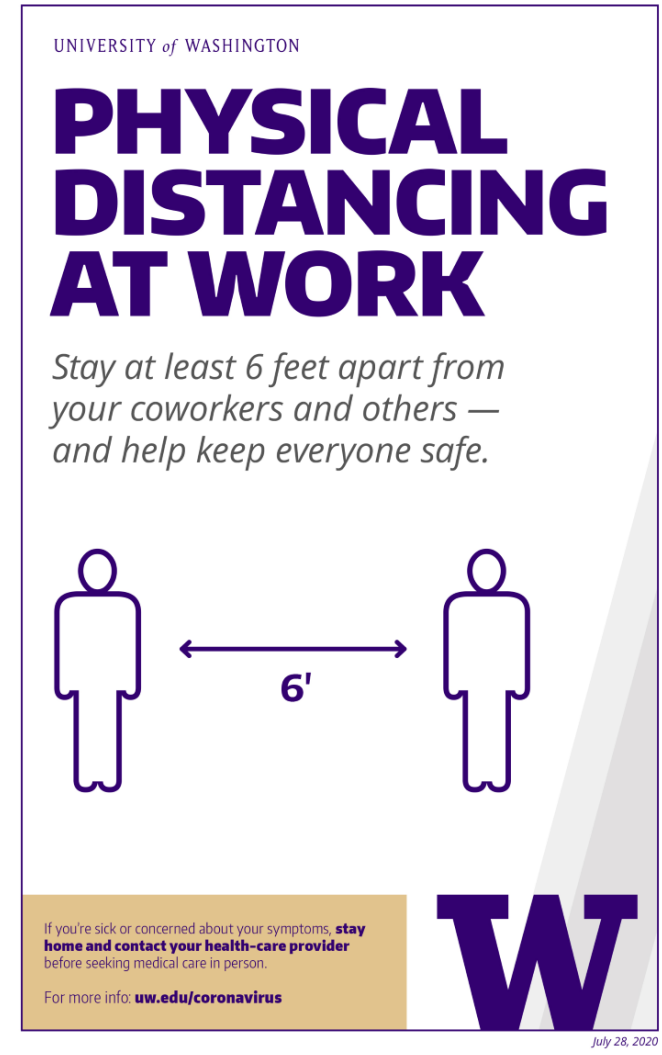

Figure 22. ${ }^{21}$

\section{Social distancing is not emotional distancing.}

Being physically apart does not mean we have to be emotionally isolated.

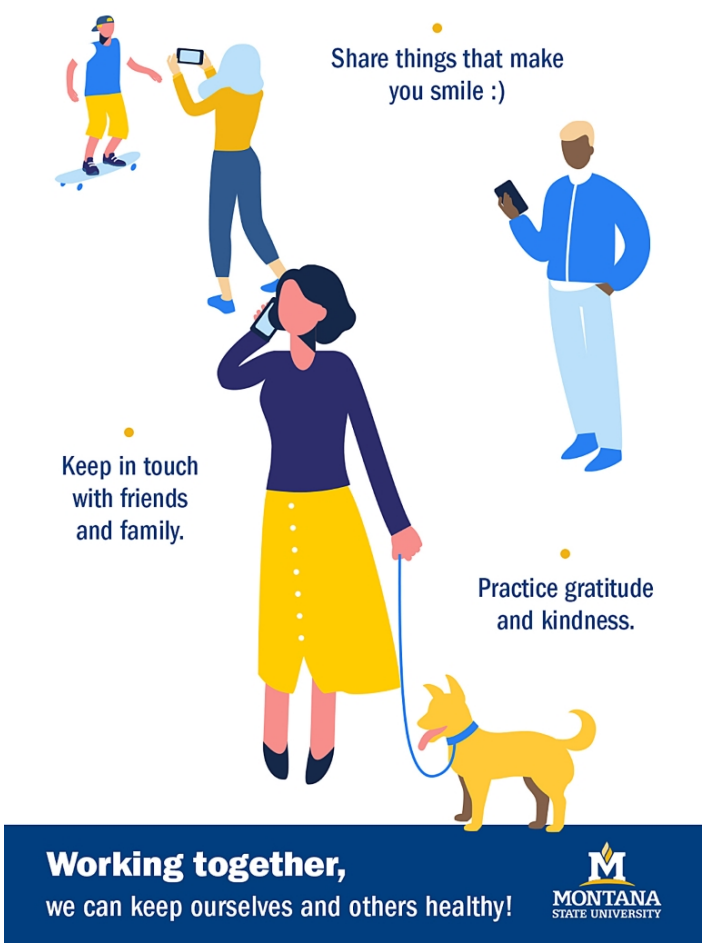

Figure 23. ${ }^{22}$

The linguistic characteristics of these texts are the use of the terms physical distance (Figure 22) and facial distance more often than social distance, in order to encourage people to communicate with each other and to understand that social distance does not mean emotional distance (Figure 23). Verbs associated with caring for each other, such as protect, help, and care are used to encourage a considerate reintegration to the campus.

\footnotetext{
${ }^{21}$ https://www. washington.edu/brand/healthy-huskies/

22 https://www . montana.edu/health/coronavirus/covid-download-gallery.html
} 


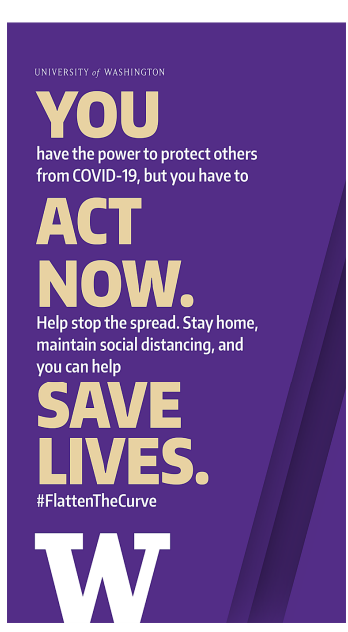

Figure 24. ${ }^{23}$

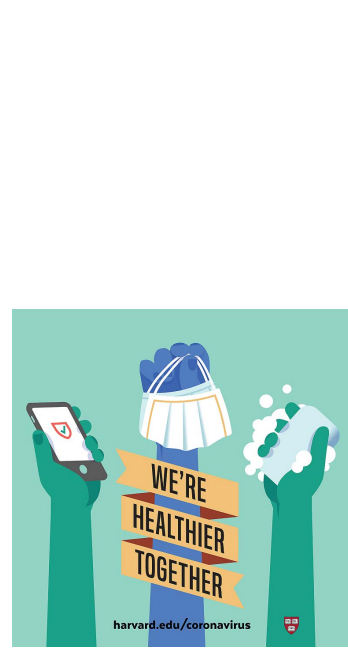

Figure 25. ${ }^{24}$

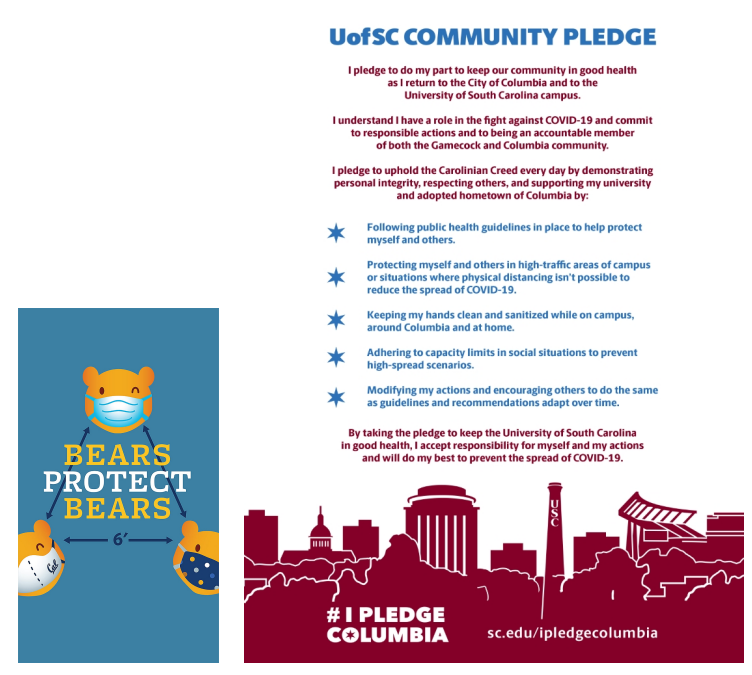

Figure 27. ${ }^{26}$

The texts of the first and second group mainly used the "you-approach" (Figure 24), explaining what each person can do to protect themself and the individuals around them. The third group focuses on the "we-approach" (Figures 25-27), emphasizing what students, faculty and staff can do together as a community to slow the spread of COVID-19 and make the process of learning safe. The words community and the names of mascots which symbolize participants of university discourse as a whole are verbal markers of the "we-approach".

Additional meanings portrayed by such nonverbal elements as the thermometer and cell phone (cell phones are used to access the COVID-19 self-screening tool and complete the necessary forms) have been added to the images introduced before.

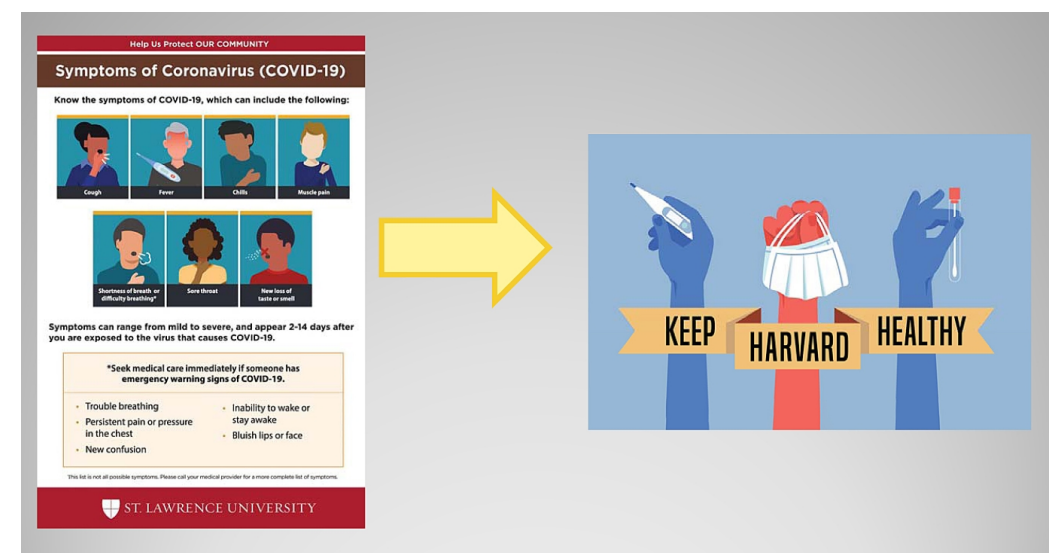

Figure 28. ${ }^{27}$

\footnotetext{
23 https://s3-us-west-2.amazonaws.com/uw-s3-cdn/wp-content/uploads/sites/98/2020/03/15145 330/Instagram-Story_ACT-NOW_200315.png

24 https: //www.harvard.edu/coronavirus

${ }^{25}$ https://uhs.berkeley.edu/coronavirus/health-information/protect-yourself-and-others-co vid-19

${ }^{26}$ https://sc.edu/safety/coronavirus/ipledgecolumbia/toolkit/index.php

${ }^{27}$ https://www.stlawu.edu/university-communications/covid-19-posters,https://www.harvard.ed $\mathrm{u} /$ coronavirus
} 
For example, the image of the thermometer was used in the multimodal texts of the first group, informing recipients about the symptoms of COVID-19. In those texts it represented the action of taking your temperature when you do not feel well, in order to see if you have a fever as one of the first symptoms of the new virus. The multimodal texts of the third group contain the image of a thermometer to remind everybody to check their temperature before every visit to the university campus to make sure that they are healthy and will not spread the virus.

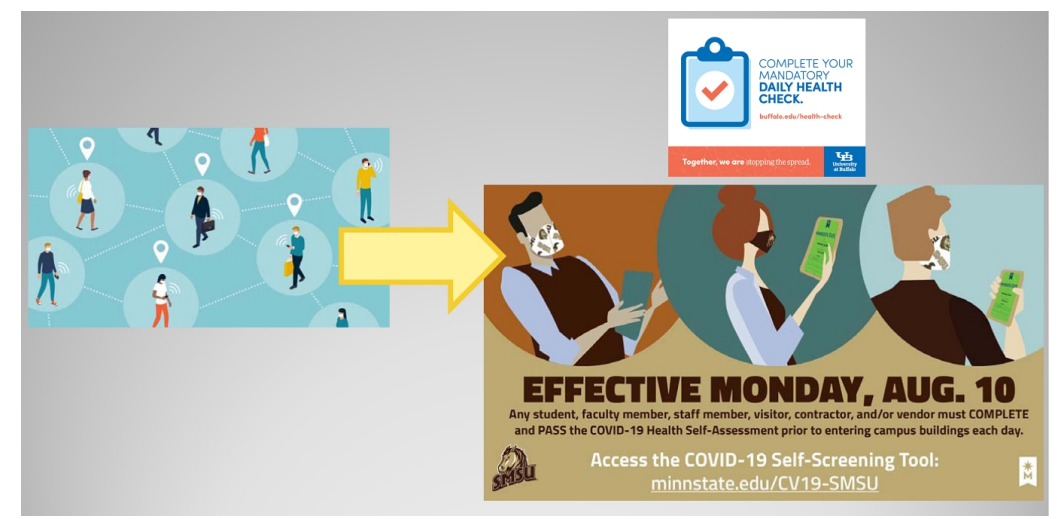

Figure 29. ${ }^{28}$

The image of the cell phone initially represented one of the alternatives for communicating during social distancing. Later on, this nonverbal element was used by discourse participants to represent access to the self-screening tool (each person had to complete a self-screening test before going on campus and cell phones were the most convenient tool for this).

The combination of verbal and nonverbal elements is used to represent certain updates to safety rules.

For example, the image of the mask as a required measure remains the same but the accompanying text gives additional information that masks are required indoors (Figure 30) and when other people are near (Figure 31).

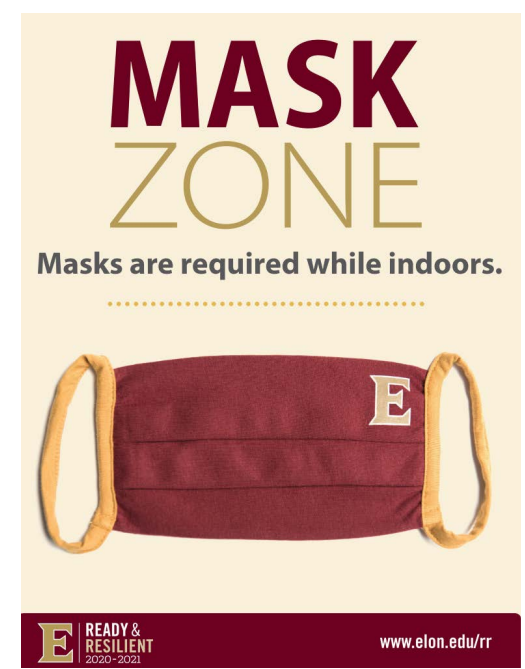

Figure $30 .{ }^{29}$

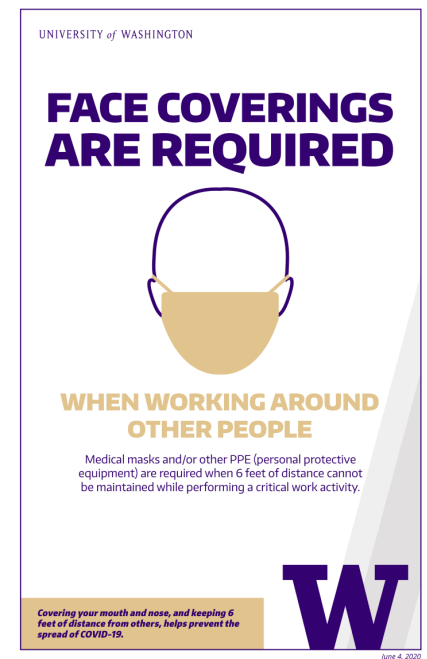

Figure 31. ${ }^{30}$

\footnotetext{
28 http://www.buffalo.edu/brand/resources-tools/ub-templates-and-tools/health-safety-resou rces.html, https://www.smsu.edu/today/articles/2020/08-07-2020_selfassessment.html

29 https://www.elon.edu/rr
} 


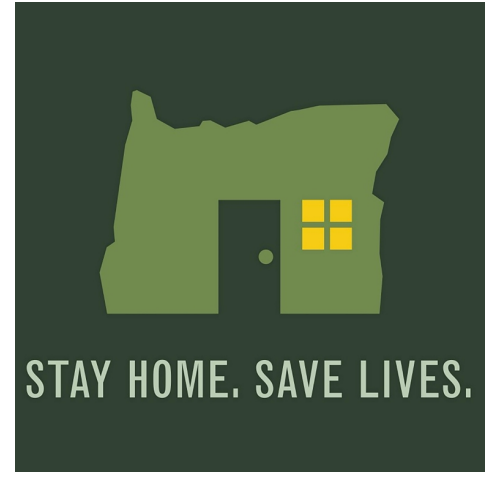

Figure 32..$^{31}$

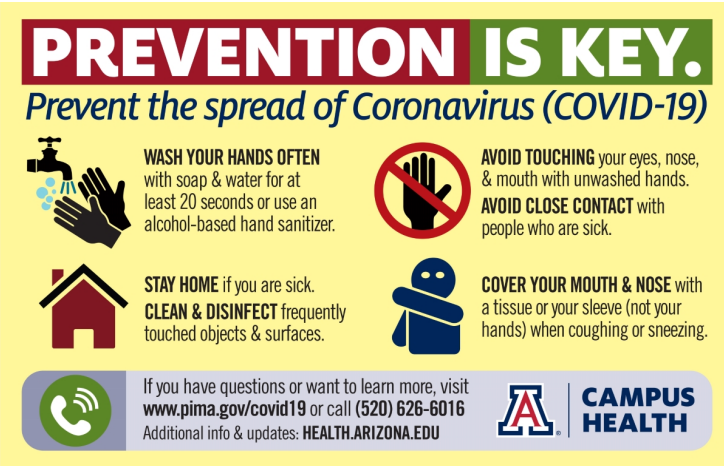

Figure 33. ${ }^{32}$

The image of the house which symbolized complete isolation at the beginning of the pandemic (Figure 32) is now used with a verbal element specifying that it is necessary to stay at home if you are ill (Figure 33).

As the participants of American university discourse try to reopen campuses, more and more multimodal texts with pictures of students studying on campus have begun to appear on university websites and social media accounts to assure recipients that all possible measures are taken to ensure safety on campus. The verbal components often include the new term a COVID conscious campus, which was coined during the pandemic (Figure 34). The nonverbal components consist of pictures depicting students and faculty in small groups and at a safe distance from each other on campus. Sometimes a picture of a mascot symbolizing the university community is added (Figure $35)$.

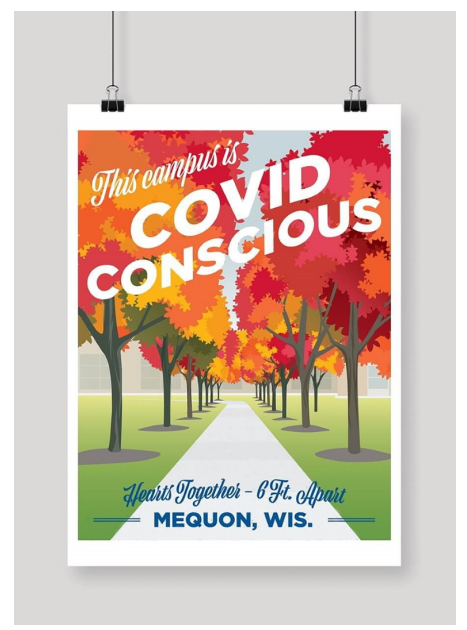

Figure $34 .{ }^{33}$

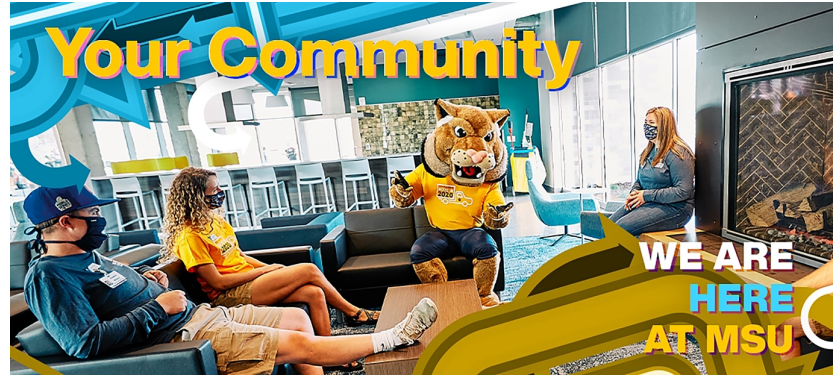

Figure 35. ${ }^{34}$

The third group of multimodal texts which appeared on university websites and social media accounts at the end of summer - beginning of fall 2020 is differentiated by its cautious and rather optimistic character. The linguistic features include the coinage of new terms such as emotional distance, physical distance and facial distance, as well as COVID conscious campus. The nonverbal

\footnotetext{
30 https://depts.washington.edu/auts/courses_inperson.html

31 https://go.okstate.edu/

32 https://health.arizona.edu/file/1003

33 https://www. cuw. edu/landingpages/uncommon-return/conscious.html

34 https://www.montana.edu/assets/images/6xwpw/image5.jpg
} 
components, familiar from the beginning of the pandemic, have acquired additional meanings. The concept of complete social distancing is no longer promoted but is often replaced with the concept of physical distancing.

\section{Conclusion}

The multimodal representation of American university discourse has experienced a number of changes during the COVID-19 pandemic. This discourse can be defined as a cognitive and communicative activity, restricted by the institutional boundaries of U.S. universities, aimed at the realization of discourse participants' status and role capabilities and the achievement of educational, social, business and marketing aims. During the pandemic, communication between discourse participants has shifted to virtual campuses on university websites. Necessary information has been made available without any time restrictions and written communication has prevailed over oral communication. The outbreak of the new virus has also led to a change in the priorities of the discourse. The aim of maintaining a safe environment and informing all participants of the necessary measures to be taken has become the top priority and university administrations have been compelled to search for new ways of achieving their other aims in the new reality imposed by the pandemic.

University websites and social media accounts have become the main channels of communication for the participants of American university discourse during the COVID-19 pandemic. Multimodal texts published on the websites and social media accounts of universities have come to be seen as key elements in the realization of the concept of a safe university environment and vital in communication between sender and recipient.

In this study, multimodal texts dedicated to the topic of COVID-19 appearing in the channels of communication of American universities have been classified into three groups based on their time of release and their portrayal of the notion of distance. Over the course of the pandemic, the content of the analyzed texts has gradually changed from active propaganda advocating complete isolation at home to a cautious promotion of reconnecting in a secure environment on campus. This is achieved through the combination of verbal and nonverbal components of multimodal texts that create a single visual, structural, semantic, and functional whole which ensures a complex, pragmatic influence on the recipient. Universities' visual materials strive to encourage diversity, equity, and inclusion, while recreating and maintaining a safe and healthy environment in the reality of the "new normal".

\section{References}

Arutiunova, N. D. (1990). Diskurs. In Lingvisticheskiı éntsiklopedicheskiน slovar' (pp. 136-137). Sovetskaia èntsiklopediia.

Bargiela-Chiappini, F., \& Planken, B. (2013). Business discourse. Palgrave Macmillan. https://doi.or g/10.1057/9781137024930

Bekhta, I. A. (2014). Mul'tymodal'ni zasoby koheziï ta koherentnosti u suchasnykh literaturnykh kazkakh: Teoretyko-metodolohichna interpretatsiia. Naukovy̌ visnyk Mizhnarodnoho humanitarnoho universytetu: Seriia. Filolohiia, 2014(13), 87-90.

Bezuhla, L. R. (2007). Verbalizatsiia implitsytnykh smysliv u nimets'komovnomu dialohichnomu dyskursi. KhNU im. V. N. Karazina.

Bieliekhova, L. I. (2015). Stereotypni slovesni poetychni obrazy v amerykans'komu poetychnomu dyskursi: Komunikatyvno-prahmatychnyı̌ aspekt. Naukovi zapysky Kirovohrads'koho derzhavnoho pedahohichnoho universytetu imeni Volodymyra Vynnychenka: Ser. Filolohichni Nauky, 2015(138), 3-9.

Bondarenko, E., Martyniuk, A., Frolova, I., \& Shevchenko, I. (2017). Kak narisovat' portret ptitsy: Metodologiia kognitivno-kommunikativnogo analiza iazyka: Kol. Monografiia. KhNU imeni V. N. Karazina.

Fairclough, N. (2018). Critical discourse analysis: The critical study of language. Routledge. 
Forceville, C. (2009). Non-verbal and multimodal metaphor in a cognitivist framework: Agendas for research. In C. Forceville \& E. Urios-Aparisi (Eds.), Multimodal metaphor (pp. 19-44). Mouton de Gruyter. https://doi.org/10.1515/9783110215366.1.19

Gee, J. P. (2014). An introduction to discourse analysis: Theory and method. Routledge.

Gee, J. P., \& Handford, M. (2012). The Routledge handbook of discourse analysis. Routledge. https: //doi.org/10.4324/9780203809068

Griebel, T., Evert, S., \& Heinrich, P. (2020). Multimodal approaches to media discourses: Reconstructing the age of austerity in the United Kingdom. Routledge. https://doi.org/10.4324/9780367332907

Karasik, V. I. (2007). IAzykovye kliuchi. Paradigma.

Karasik, V., Prokhvacheva, O., Zubkova, IA., \& Grabarova, Ė. (2005). Inaia mental'nost'. Gnozis.

Kress, G. R., \& Leeuwen, T. van. (2017). Multimodal discourse: The modes and media of contemporary communication. Bloomsbury Academic.

Kress, G. R., \& Leeuwen, T. van. (2020). Reading images: The grammar of visual design. Routledge. https://doi .org/10.4324/9781003099857

Levchuk, P. (2019). Ukrainian, Polish and Russian trilingualism among Ukrainians of non-Polish origin living in Poland. Cognitive Studies / Études cognitives, 2019(19), Article 1988. https://doi.org/10 $.11649 /$ cs. 1988

Machin, D., \& Leeuwen, T. V. (2016). Multimodality, politics and ideology. Journal of Language and Politics, 15(3), 243-258. https://doi.org/10.1075/jlp.15.3.01mac

Makaruk, L. (2014). Spetsyfika suchasnoho anhlomovnoho mul'tymodal'noho dyskursu. East European Journal of Psycholinguistics, 1(2), 70-78.

Ostanina-Olszewska, J., \& Majdzińska-Koczorowicz, A. (2019). A Cognitive Linguistics approach to internet memes on selected Polish internet sites. Cognitive Studies / Études cognitives, 2019(19), Article 1939. https://doi.org/10.11649/cs.1939

Prikhod'ko, A. (2013). Kontsepty i kontseptosistemy. Belaia E. A.

Shevchenko, I. S. (2005). Dyskurs iak myslennievo-komunikatyvna diial'nist'. In I. S. Shevchenko \& O. I. Morozova (Eds.), Dyskurs iak kohnityvno-komunikatyvnyて fenomen (pp. 21-29). Konstanta.

The publication was financed at the author's expense.

The author declares that she has no competing interests.

(3) This is an Open Access article distributed under the terms of the Creative Commons Attribution 3.0 PL License (http://creativecommons.org/licenses/by/3.0/pl/), which permits redistribution, commercial and non-commercial, provided that the article is properly cited.

(C) The Author 2021

Publisher: Institute of Slavic Studies, Polish Academy of Sciences

Publishing history: Received 2020-08-06; Accepted 2021-02-12; Published 2021-10-11. 